\title{
Inhaltsübersicht
}

\section{Teil 1: Das Mittelalter}

Teil 1, Das Mittelalter .................. Seite Inhaltsverzeichnis Teil $1 \ldots \ldots \ldots \ldots \ldots \ldots \ldots$.

1. Karl der Große und seine Nachkommen ......... 3

2. Der vollendete Feudalstaat ................. 99

3. Das hohe Mittelalter ................... 261

4. Das späte Mittelalter . . . . . . . . . . . . . . . . 489

5. Die Schweizer ...................... 629

Einleitung zum Nachdruck .............. 771

Namen- und Sachregister (von Teil 1) ......... 783

\section{Teil 2: Die Neuzeit}

(beginnt hinter Seite 793 des ersten Teils in diesem Band)

Teil 2, Die Neuzeit................... Seite Inhaltsverzeichnis Teil $2 \ldots \ldots \ldots \ldots \ldots \ldots \ldots . \mathrm{V}$ Vorwort ........................... IX

1. Das Kriegswesen der Renaissance............... 3

2. Das Zeitalter der Religionskriege ............. 151

3. Die Epoche der stehenden Heere ............. 285

4. Die Epoche der Volksheere. . . . . . . . . . . . . . 505

Einleitung zum Nachdruck ................6 601

Namen- und Sachregister (von Teil 2) . . . . . . . . 619 



\section{Hans Delbrück}

\section{GESCHICHTE DER KRIEGSKUNST}

\section{Teil 1}

Das Mittelalter

Von Karl dem Großen

bis zum späten Mittelalter

Mit einer Einleitung von Kurt-Georg Cram 
